\title{
Manju Kapur's The Immigrant: A Saga of Marital Disharmony
}

\author{
Dr. Bajrangi Lal Gupta \\ Assistant Professor \\ Gorakhpur, Uttar Pradesh, India \\ blengrs88@gmail.com
}

\begin{abstract}
Manju Kapur's fourth novel The Immigrant was published in 2008 and was shortlisted for the DSC prize for South Asian Literature. It was subtitled by Kapur as 'a truly compelling portrait of an arranged marriage' in which she explores the depths of an Indian woman's mind struggling in search for her own happiness in a foreign country. The novel also deals with the problems of woman aspiring for higher life in general. It is a mesmerizing saga about the complexities of marriage and NRI life by Kapur. The paper is an attempt to show the loneliness, suffocation and longing of a modern woman in an arranged marriage in the context to Indian society.
\end{abstract}

Keywords: Marriage, Loneliness, Longing and Suffocation.

Marriage is an important event in the life of a woman which is celebrated as a significant event in the family and society at large. Simone de Beauvoir's well known statement in The Second Sex regarding marriage is quite evident. "Marriage is the destiny traditionally offered to women by society. It is still true that most women are married or have been, or plan to be, or suffer for not being" (The Second Sex 445). Marriage is the biggest concern for an Indian girl whether she is self-dependent or dependent. In Indian society the girl is learnt at early that she is 
Paraya Dhan means another's property. In India it is supposed to be a sacred institution and also a mandatory for every female. In this country the marriage of a girl is taken as a big responsibility of parents. In our society a woman has no separate identity. She is seen in relation to her husband. If she goes against it, the society creates trouble in her life.

Manju Kapur is one of the most accomplished Indian women writers. She in almost all her novels focuses her attention on the problems of middle class women. She in her novels has presented the suffocation and longing of a married woman in a male dominated society. In the novels of Kapur man-woman relationship has been presented with psychological insight. In her debut novel Difficult Daughters, Virmati's mother, like other traditional Indian mothers, thinks that a girl is born to be married. The same issue we see in the case of her second and third novels A Married Woman and Home where Astha's mother and Nisha's parents are anxious for their daughters' marriage. Nina's mother in The Immigrant also thinks of her daughter's marriage though she knows that after her marriage she would be alone.

The story of the novel begins with Nina, who is thirty years old having radiant complexion and jet black hair and still unmarried. "Her heart felt a hundred as it surveyed the many years of hopeless longing it had known." (The Immigrant 1) She teaches at Miranda House College and lives with her mother at B-26 Jangpura Extension in Delhi. Her mother's prime concern was to get her daughter marry as she was fatherless and the responsibility was on her shoulder. "The major topic of conversation in the last eight years had been Nina's marriagewho, when, where, how?" (The Immigrant 2) Contrary to it Nina believes in, "education was a gift and she would not exchange the life of the mind for any humdrum marriage." (The Immigrant 3) Nina's friend Zenobia is with her who often urges Nina to go abroad for further studies which might help her in finding a suitable guy as, "Indian men were mother-obsessed, 
infantile, chauvinist bastards."(The Immigrant 8) But Nina's present situation does not allow her to apply for Ph.D. Nina and her mother often quarrel over the topic of marriage. She persuades her of every kind by saying, "if you married an NRI or someone in the foreign services you could live abroad nicely."(The Immigrant 11) but Nina was opposite to it, she said, "if a husband could protect her from life in a brutal autocratic state she would marry him tomorrow."'(The Immigrant 11) This could not stop Nina's mother to think of her marriage, she took Nina to an astrologer who told them that marriage would take place this year or next. At the same time Nina's mother comes to know about a good relation. The name of the boy was Ananda, a year older than Nina.

Ananda was a dentist, lived in Canada. His life was also full of miseries as his parents died in a road accident and on the request of his maternal uncle, he had to leave for Halifax, Canada. There he got an enrollment in Dalhousie University, the biggest university in Nova Scotia. With the help of his uncle and his friend Gary he settled there and became a respected member of society. In between Alka, his sister brought her poor brother's need for an Indian wife but Ananda took it negatively. According to him, "a wife from India meant India Club, meant socializing with Immigrants, pretending they had a bond."(The Immigrant 46) Alka insisted him by saying, "a wife will help you settle. Ma's spirit will not rest in peace till you are married.'(The Immigrant 46) Alka sends the picture of Nina to him and persuades him for this relation. Ananda becomes fascinated at the beauty of Nina and finds himself helpless to ignore it. Kapur writes, "In his anxiety to establish himself he had turned his back on India and Indians."(The Immigrant 49) On the approval of Alka, Ananda comes to see to Nina and gives his positive sign to this relation. But Nina did not feel the spark of instant attraction as she was in a great confusion. She thinks about the causes why she should accept this? "She wanted a family, 
she wanted children, she wanted to make her mother happy. Millions of women married for such reasons.”(The Immigrant 70) As for her Ananda was a stranger. She was in great dilemma as her mother had told her that, "marriage is a question of adjustment."(The Immigrant 74) She should not avoid this as "it was necessary to have a man to protect one from the vicissitudes of life? Somehow she had not managed to teach Nina the concepts of society."(The Immigrant 74) After the months of contemplation and confusion, she gave her positive sign to this relation keeping in mind, "the desire of her, impatience for marriage, an eagerness to build a future together."(The Immigrant 79) Now the wedding was fixed and was solemnized in an Indian custom. At the bridal night Ananda due to his sexual problem failed to prove himself and Nina on the other hand imagined her previous closeness with Rahul, her ex-boyfriend. At the same time she too realized the essence of togetherness. "Togetherness was the important thing. To be critical of how it was against the spirit of marriage."(The Immigrant 90) After three days Ananda departed Canada leaving her wife in Delhi as Nina's passport was not ready. It would take three months to complete. Now Nina had to return to her home and then at the college in the form of a married woman. "She never anticipated though the respect that came with marriage, a tiny shift in focus and there it was; Nina Sharma, an accepted member of society, married, bound for the Western big time."(The Immigrant 99) Now the time came and she had to leave everything her mother, her friends, the busy life schedule and her college.

On the way to Canada Nina had to suffer different kind of humiliation. At London airport she was ignored by a sweeping woman who was looking Indian in her dressing sense. "For the first time in her life Nina felt out of place. Wrong clothes, shoes, handbag, bag. May be in their eyes she was like the woman sweeping."(The Immigrant 104) This was not stopped, her experiences of being an immigrant at Toronto airport was another kind of humiliation. At the 
immigration counter Nina was asked about her husband and in her answer she was told to stop aside. She was kept in a small empty cubicle with neon lights and no windows. It was like a jail in the view of Nina. After some time a white woman came and asked a lot of questions related to her relatives, her husband, and about her professional qualifications. Nina was stunned as she had no idea why these were happening to her. That white lady even examined the photographs shown by Nina, the wedding invitation, the marriage certificate and the other things Ananda had asked to carry. When the woman allowed Nina to go, she felt soiled. She was feeling accused of trying which was not less. In her heart she was blaming Ananda to be responsible for her humiliation but she was stopped by her mind for this unreason. She thinks, "if he is responsible for her coming here, she is responsible for having chosen to marry an NRI. There exist some rotten eggs everywhere.”(The Immigrant 107)

In Canada her life was much easier. Here she was not a deprived onlooker but her status was like a consumer who was ready to consume everything. But one thing which made her troubled was her aloneness. As Ananda left her at the compartment and went for his clinic. She used to spend her leisure time by reading book but that was not enough. She demanded Ananda of more reading materials but he in return advised her to spend time with watching T.V. "Nina had never watched T.V. in her life. She required the printed word to fill the spaces in her mind, the leisured turning of pages, the slow absorption of words, the occasional re-reading. She wondered whether this suggested some rigidity of outlook."(The Immigrant 120) Nina was helpless and alone. She found her life friendless and purposeless there. Though she had everything but those were unable to soothe her. We see that her condition was like those "immigrant who comes as a wife has a more difficult time. If work exists for her, it is in the 
future and after much finding of feet. At present all she is, is a wife, and a wife is alone for many, many hours.'(The Immigrant 122)

After their marriage Ananda and Nina had everything except a baby. Though Nina was in favour of it but for Ananda it was not important. She had none except Ananda she could talk and share. In her loneliness she thinks about a baby, "If she had a baby, the next twenty years would be taken care of. Her interest in Canada would grow, her child's home after all."(The Immigrant 160) But Ananda did not want to hear such types of implications. For him, "they have not been married that long, what is the hurry."(The Immigrant 161) Ananda never tried to read Nina's feeling, even when it was quite easy to know that she was not satisfied. Though she could not come to know what normal sex life is. Nina never complained as she believed that togetherness is the essence of a successful married life. She insisted, "We should tell each other all our feelings. I don't want any shadows in our married life.’(The Immigrant169)

Nina like other Asian woman feels insecure without children. But Ananda was indifferent to her suffering. He thinks, "to get pregnant as soon as you are married was a very stupid, backward thing to do, it was more important to settle down first." (The Immigrant 169) Ananda never shared anything with Nina. He had even concealed his inadequacy to Nina. He even went for a treatment for his sexual problem secretively, with the help of an unknown lady rather his own wife. He was afraid that negative results would be an attack on his manhood. Nina was furious when she came to know the reality. But Ananda persuaded her by saying that he did not want to expose her most private moments to a sex therapist. Though, she was not satisfied with Ananda in this regard. She tried to seek relief from her aggravation in her part time job at the library and the co-counselling group of a friend, Beth. "She was now less enthusiastic about a baby, but this only made her feel empty. All her expectations of marriage and her future had 
been bound up in motherhood." (The Immigrant 215) Nina was so much confused about her future in Canada. She even, was not sure about her desires as her teaching experience in India was worthless. Everything was strange to her and she panged for her previous life in India. "I used to be teacher, in fact I taught for ten years before I came here. And now I do nothing. I have not even been able to conceive. Am I locked into stereotypical expectations?"(The Immigrant 229) Gradually, motivated by this group, she decided to find her feet in this country by taking admission in a Library School. Now here she was very happy among the students of the Library School. During the course she came into contact with Anton, a settler in America. Both of them seemed to be satisfied in their company. In his company she felt relaxed and it was a different kind of experience for herself, her peculiarity, autonomy and her independence. Nina seemed to get full pleasure during her physical relationship with Anton. "For the first time she had a sense of her own self, entirely separate from other people, autonomous, independent. So strange that the sex did not make her feel guilty, not beyond the initial shock." (The Immigrant 260)

In this way Nina was making his own route and Ananda did not interfere in it as he was already engaged with Mandy, his receptionist. Even on the death of her mother he did not accompany her and gladly made all the required arrangements for her departure. After the death of Nina's mother, she found her life quite difficult as there was no one with whom she could talk or share her feelings and emotions. Anton with whom she was once deeply attached, even he raped her. She found herself dejected at all the fronts and was trying to live her life on her own way, though it was not easy for her. Manju Kapur writes, "Her own existence seemed poor in comparison. With no mother to disappoint, nobody's expectations to meet, the bonds of her marriage assumed a different feet. Her life was now completely her own responsibility, she could blame no one, turn to no one. She felt adult and bereft at the same time."(The Immigrant 323) 
Now what we find in the novel is that Nina and Ananda who were once united by the institution of marriage, are free from the restraint of this. The lack of trust, love and fidelity are responsible for their marital disharmony. The lack of these emotions causes mental agony too. Kamala Das in her autobiography writes, "a broken marriage is as distasteful, as horrifying as an attack of leprosy." (My Story 4) 


\section{Works Cited}

Beauvoir, Simone de. The Second Sex. Trans. H. H. Parshley. London: Vintage Books, 1997. Das, Kamala. My Story. New Delhi: Sterling Pvt. Ltd. 1988.

Kapur, Manju. The Immigrant. New Delhi: Random House, 2008.

Web sources- www.indiabookstore.net/bookish/review-the-immigrant-by-manju-kapur/ www.shodhganga.inflibnet.ac.in 